\title{
THE IMPACT OF PHYSICAL AND SPORTS REHABILITATION OF PEOPLE WITH CEREBRAL PALSY ON THE PROPRIOCEPTIVE SYSTEM IMPROVEMENT
}

\author{
Olha Herus ${ }^{1}$, Tereza Klymus ${ }^{2}$, Marta Kozak ${ }^{3}$ \\ Lviv National Polytechnic University, Lviv, Ukraine
}

\begin{abstract}
.
Introduction: Cerebral palsy occurs as a result of affecting those parts of the central nervous system that control the muscles and are responsible for the balance and movements arbitrariness. It has a number of forms with varying degrees of damage to the central nervous system and impaired physiological functions. And this certainly affects the perception. Due to perception distortion, sensory interpretation is slowed down and incorrectly analyzed in the cerebral cortex. The improvement of the motor sphere implies the development of general and small motor skills, and the improvement of movements coordination. The correction of motor sphere disorders should be done in a comprehensive, systematic manner, with the involvement of specialists (neurologists, physical therapists, rehabilitologists, sensory therapists). This will help to determine the content of motor sphere correction exercises and define the step-by-step measures for physical condition improvement.
\end{abstract}

Aim: to investigate the impact of physical and sports rehabilitation measures of people with cerebral palsy disabilities on improving the proprioceptive system basing on an analysis of the practical application of the bocce game program.

Methodology: SIPT (Sensory Integration and Praxis Tests) breach detection study. Bocce game lessons were tested (as a method of physical and sport rehabilitation) in order to improve the sensory system. Object of the study 10 people aged 28-35 with a clinical diagnosis of "Cerebral palsy" with impaired mobility, who are using a trolley and are undergoing rehabilitation at the rehabilitation center in Lviv.

Results: It was found that 9 out of 10 participants had dysarthric disorders. General somatic attenuation and slow development of locomotor functions are accompanied by a lag in the motor sphere development of the people with cerebral palsy.

Conclusion: The study found that engaging in sports and exercise leads to increased physical health and improved gross fine motor skills related to the sensorimotor system.

Keywords: cerebral palsy, physical and sports rehabilitation, Bocce game, dysarthric disorders, sensory integration, SIPT (Sensory Integration and Praxis Tests)

The authors declare that they have no competing interests 


\section{References}

Ayres, A. J. (1969). Deficits in sensory integration in educationally handicapped children. Journal of Learning Disabilities, 2, 160-168. https://doi.org/10.1177/002221946900200307

Ayres, A. J. (1989). Sensory integration and praxis tests. Los Angeles: Western Psychological Services.

Ayres, A. J., \& Tickle, L. S. (1980). Hyper-responsibility to touch and vestibular stimuli as a predictor of positive response to sensory integration procedures by autistic children. The American Journal of Occupational Therapy, 34, 375-381.

Baranek, G. T. (1998). Sensory processing in persons with autism and developmental disabilities: considerations for research and clinical practice. Sens. Integr. Spec. Interest Sect. Q. 21, 1-3.

Bocce v Ukraini (2017). Website. http://www.boccia.org.ua/about-boccia/.

Fisher, A. G., \& Murray, E. A. (1991). Introduction to sensory integration theory. In A. G. Fisher, E. A. Murray, \& A. C. Bundy (Eds.), Sensory integration: Theory and practice. Philadelphia: F. A. Davis, 3-26.

Kolchenko, K., \& Nikulina, H. (2009). Zabazpechennia inkliuzii molodi z invalidnistiu v universytetske seredovysche. Aktualni problem navchannia ta vychovannia liudei z osoblyvymy potrebamy: zbirnyk naukovych pratc, 6(8), 10-15.

Matvyeyev, S., Kohut, I., Radchenko, L., Borysova, O. \& Scherbatyn, Ia. (2004) Shliachy udoskonalennia phizkulturno-sportyvnoi roboty z invalidamy $\mathrm{V}$ Ukraini. Teoriia metodyka vychovannia i sportu, 2, 109-112.

Williamson, G., \& Anzalone, M. (1997). Sensory integration: A key component of the evaluation and treatment of young children with severe difficulties in relating and communicating. Zero To Three, 17 (5), 29-36 


\title{
ВПЛИВ ЗАХОДІВ ФІЗКУЛЬТУРНО-СПОРТИВНОЇ РЕАБІЛІТАЦЇ̈ ОСІБ 3 ІНВАЛІДНІСТЮ 3 ЦЕРЕБРАЛЬНИЙ ПАРАЛІЧЕМ (ДЦП) НА ПОКРАЩЕННЯ ПРОПРІОЦЕПТИВНОЇ СИСТЕМИ
}

\author{
Ольга Герус ${ }^{1}$, Тереза Климус ${ }^{2}$, Марта Козак ${ }^{3}$ \\ ${ }^{1}$ к.соц.н., асистент кафедри соціології та соціальної роботи, \\ Національний університет «Львівська політехніка», \\ ${ }^{2}$ к.пед.н., старший викладач кафедри соціології та соціальної роботи, \\ Національний університет «Львівська політехніка», \\ ${ }^{3}$ к.б.н., доцент кафедри соціології та соціальної роботи, \\ Національний університет «Львівська політехніка»,
}

Анотація. Церебральний параліч (ДЦП) виникає внаслідок ураження тих відділів центральної нервової системи, що контролюють роботу м'язів, відповідають за рівновагу і довільність рухів. ДЦП має ряд форм з різним ступенем ураження ЦНС і порушенням фізіологічних функцій організму. При цьому, безумовно, страждає сприйняття. Через спотворення в сприйнятті, сенсорна інтерпретація сповільнюється і невірно аналізується в корі головного мозку. Удосконалення рухової сфери передбачає розвиток загальної та дрібної моторики, поліпшення координації рухів. Корекція порушень рухової сфери має відбуватися комплексно, систематично, із залученням фахівців (лікаряневропатолога, фізичного терапевта, реабілітолога, сенсорного терапевта). Саме вони допоможуть визначити зміст занять 3 корекції рухової сфери та поетапні кроки щодо поліпшення фізичного стану.

Ключові слова: церебральний параліч (ДЦП), заходи фізкультурноспортивної реабілітації, гра бочче, дизартричні розлади, сенсорна інтеграція, шкала SIPT (Sensory Integration and Praxis Tests).

Актуальність дослідження. У довгостроковій перспективі терапія 3 сенсорної інтеграції може зменшити потребу адаптації та допомогти людям стати більш функціональними вдома, у школі та на робочому місці. Сенсорні проблеми можна виявляти лише шляхом спостереження за поведінкою особи та того, як вони реагують та взаємодіють у своєму звичному середовищі. Вони можуть впливати на кожен аспект життя та повсякденної дії особи.

Особи, у яких виявлено порушення у сенсорній обробці інформації, можуть мати також проблеми 3 координацією рухів. У них можуть бути виявлені проблеми з дрібної моторики, яка необхідна для таких дій, як написання, гра на інструментах, формування навичок з самообслуговування, такі як зав'язування шнурівок, защіпання кнопок. Труднощі 3 грубою моторикою необхідною для формування навичок з сидіння, бігу, стрибків, які у свою чергу матимуть вплив на навчання їзди на велосипеді, одягання, танцювання, можуть спричинювати труднощі на уроках фізичного виховання та зайняттям іншими видами спорту.

Наукова і практична проблема полягає у тому, що в спеціальній літературі не достатньо висвітлена тема допомоги особам 3 порушенням обробки та інтеграції сенсорних сигналів, зокрема 3 порушенням опорнорухового апарату через фізичні навантаження і спорт. Терапія сенсорної інтеграції вважається ефективним методом для таких випадків, а також може 
поліпшити стан і при ряді інших діагнозів, порушень, зокрема i не діагностованих причин дискомфорту від різних подразників.

Аналіз досліджень і публікацій. Вагомий внесок у розвиток сенсорної інтеграції описані зайняттєвим терапевтом Дж. Аерс (Ayres, 1969 \& Ayres, 1989) та нею введені в обіг такі поняття як сенсорна депривація, яка пов'язана із порушенням сенсорних відчуттів, сенсорна обробка інформації. Особливості впровадження сенсорної інтеграції досліджували такі науковці як: Дж. Аерс та Л. Тікл (Ayres \& Tickle, 1980), М. Вільямсон та Г. Анзалоне, (Williamson \& Anzalone, 1997), Г. Баранек (Baranek, 1998), ними виокремлено узгодження певних сенсорних відчуттів на зменшення чи подолання збудження (збільшення нейронних порогів чутливості).

Мета дослідження: на основі аналізу практичного застосування програми гри бочче, дослідити вплив заходів фізкультурно-спортивної реабілітації осіб 3 інвалідністю 3 церебральним паралічем (ДЦП) на покращення пропріоцептивної системи.

Об'скт дослідження: заходи фізкультурно-спортивної реабілітації як заняття з бочче для осіб з інвалідністю з церебральним паралічем (ДЦП).

Предмет дослідження: особливості впровадження занять гри бочче через адаптацію та модифікацію спортивних занять для осіб з ДЦП.

У теорії сенсорної інтеграції виокремлюють два види порушення планування рухів: BIS (bilateral integration and sequencing) i соматодиспраксію (SD). 3 точки зору поступального дефіциту мають значення такі показники: тонус м'язів розгинаючих; підтримка рівноваги; стабільність проксимальних відділів кінцівок; здатність згинати шию супроти дії сили тяжіння. Праксис (грец. pragma - дія) - складний комплекс аналітико-синтетичних процесів, спрямованих на організацію цілісного рухового акту, тобто, - це автоматизоване виконання завчених рухів. Для виконання таких рухів «на єдиному подиху» необхідні достатня зоровопросторова орієнтування i постійне надходження інформації про хід виконуваних дій.

Особи 3 ДЦП досить часто відчувають страх перед рухом (гравітаційну невпевненість), непропорційний їхнім моторним порушенням (Fisher \& Bundy, 1989). Гравітаційна невпевненість проявляється у вигляді страху рухатися, коли тіло відхиляється від вертикального положення чи коли ноги відірвані від землі. Реакція пов'язана із гравітаційною невпевненістю та послабленням переробки інформації від отолітової частини вестибулярної системи.

Таким чином, провідна роль вестибулярного аналізатора, який здійснює функцію рівноваги тіла, як у стані спокою (отолітовий апарат статика), так i під час руху (ампулярний апарат - кінематика) $\epsilon$ беззаперечною, оскільки разом вони виконують стато-кінематичну функцію.

Фізкультурно-спортивна реабілітація - це система заходів, розроблених iз застосування фізичних вправ для відновлення здоров'я особи та спрямованих на відновлення i компенсацію за допомогою занять фізичною культурою i спортом функціональних можливостей їі організму для поліпшення фізичного i психологічного стану (Matveiev et al, 2004).

Метою заходів фізкультурно-спортивної реабілітації людини 3 інвалідністю є оптимізація дій, скерованих на інтеграцію осіб з обмеженими можливостями до активного життя у суспільстві, покращення їх фізичного i 
функціонального стану та відновлення їх працездатності засобами фізичної культури і спорту.

Існує три види заходів 3 фізкультурно-спортивної реабілітації для людей з інвалідністю, а саме:

- реабілітаційно-спортивні збори для людей з інвалідністю;

- всеукраїнські оздоровчі табори для людей з інвалідністю;

- табори фізкультурно-спортивної реабілітації для людей 3 інвалідністю.

Потрібно враховувати, що наявна програма фізичного виховання людей з інвалідністю, що перебувають у системі соціального забезпечення, не відповідає вимогам, які ставляться до методичних матеріалів подібного рівня. У ній недостатньо враховуються особливості категорії людей 3 інвалідністю, специфіка моторної активності й функціонального стану організму різних категорій людей 3 інвалідністю. Можливо, саме це й обумовлює низький рівень ефективності фізкультурно-оздоровчої роботи, недостатню кількість методичних матеріалів 3 організації занять, незадовільну оснащеність спортивним інвентарем та обладнанням. Методика, як правило, зводиться до стандартного набору, який використовується в школі для здорових дітей (Kolchenko \& Nikulina, 2009).

Однією із методик фізичної реабілітації людей з порушенням опорнорухового апарату є гра бочче.

Бочче (іт. Воссе - кулі) - спортивна гра на точність, що належить до родини ігор 3 м'ячем, близька до боулінгу, петанку та боулзу, що мають спільні витоки в античних іграх, поширених на території Римської імперії. Назва гри походить від латинського слова bottia - « м'яч ». Керівним органом є CP-ISRA - Міжнародна Асоціація Спорту і відпочинку для людей з ДЦП. У 1984 p. гра стає паралімпійським видом спорту (http://www.boccia.org.ua/about-boccia/).

На перших етапах гра придумана для реабілітації людей з дитячим церебральним паралічем, пізніше в неї розпочинають грати і 3 іншими важкими захворюваннями: міопатія, пошкодження шийного хребта.

Особливої уваги заслуговує модифікація та адаптації гри для людей, які пересуваються на візках та тростині. Візки для змагань мають бути максимально наближені до стандартних; втім, дозволяються зміни, зроблені для використання візка/тростини у повсякденному житті. Також дозволяється використовувати скутери. Не дозволяється використання рефлекторів, за допомогою яких спортивні асистенти ВС3 можуть дивитися на корт. Максимальна висота сидіння, включно з подушкою чи елементами для підтримки,складає 66 см від підлоги до найвищої точки, у якій сідниці торкаються подушки. Якщо з медичних причин сидіння візка нахилене, вимір необхідно робити від підлоги до точки зосередження ваги. Це найнижча точка сідниці.

У своєму сучасному вигляді гра бочче стала популярною останнім часом, зокрема, як спорт для людей з проблемами опорно-рухового апарату.

Одночасно грають команди від 1 до 3 осіб, відповідно м'ячі діляться на всіх гравців порівну.

Вага м'яча: 275 г +/-12 г.

Окружність: 270 мм +/-8 мм. 
Важливо зазначити, що саме такий підхід із врахуванням особливостей людей з ДЦП через заняття у бочче сприятиме покращенню маніпулювання однією рукою (in-hand manipulation) i включатиме дві компоненти: переміщення (translation) - переміщення предмету від кінчика пальців до долоні (наприклад захват м'яча для гри у бочче), обертання (rotation) - обертання об'єкта навколо осі.

У самій грі існує сім дисциплін гри. У кожній дисципліні можуть грати учасники будь-якої статі. Це наступні дисципліни:

Iндивідуальна BC1. У цій дисципліні змагаються спортсмени, які класифіковані як ВC1 згідно з системою класифікації BISFed. Спортсменові може допомагати один спортивний асистент, який має знаходитися у спеціально відведеному місці позаду ігрового боксу. Спортивному асистентові у категорії ВС1 не дозволяється впливати на кидок, наприклад, розташовувати візок певним чином або котити м'яч без відповідних вказівок від спортсмена. Спортивний асистент не повинен мати прямий фізичний контакт зі спортсменом під час здійснення кидка чи удару по м'ячу. Спортивні асистенти виконують наступні завдання: регулювання положення візка чи утримання його у нерухомому стані (якщо спортивний асистент залишається у зоні гравця, але не тримає візок, це не вважається порушенням); передавання м'яча спортсменові; перекочування м'яча, щоб надати йому більш сферичної форми.

Індивідуальна BC2. У цій дисципліні змагаються спортсмени, які згідно 3 системою класифікації BISFed класифіковані як ВС2. Для спортсменів не передбачена допомога спортивного асистента під час матчу. Вони можуть просити суддю про допомогу (у межах відведеного їм часу), щоб підняти м'яч, який випадково впав, або вийти на корт.

Індивідуальна ВC3. У цій дисципліні змагаються спортсмени, які згідно з системою BISFed класифіковані як ВC3. Кожному спортсменові дозволяється користуватися допомогою спортивного асистента, який перебуває у зоні гравця, але має стояти спиною до корту і не дивитися на гру. Асистентові не дозволяється впливати на кидок, наприклад, розташовувати візок чи рампу певним чином або котити м'яч без відповідних вказівок від спортсмена. Асистентові не дозволяється дивитися на корт, налаштовуючи положення рампи. Спортивний асистент не повинен мати прямий фізичний контакт зі спортсменом під час здійснення кидка, зокрема, не можна допомагати спортсменові, штовхаючи або змінюючи положення візка чи вказівника.

Iндивідуальна BC4. У цій дисципліні змагаються спортсмени, які згідно з системою класифікації BISFed класифіковані як BC4 - гравці 3 захворюваннями не церебрального характеру та гравці категорії ВС4, які грають ногами. Спортсмен має обрати, використовувати верхні чи нижні кінцівки, щоб штовхати м'яч. Для гравців класу ВС4, які кидають м'яч рукою, не передбачена допомога спортивного асистента. Вони можуть просити суддю про допомогу (у межах відведеного їм часу), щоб підняти м'яч, який випадково впав, або вийти на корт. Гравці класу BC4, які грають ногами, згідно з класифікаційною системою BISFed, можуть користуватися допомогою одного спортивного асистента, який має знаходитися у спеціально відведеному місці позаду ігрової зони (бокса). Спортивному асистентові у класі ВС4 не дозволяється впливати на кидок, наприклад, 
розташовувати візок певним чином або котити м'яч, без відповідних вказівок від спортсмена. Спортивний асистент не повинен мати прямий фізичний контакт зі спортсменом під час удару по м'ячу. Спортивні асистенти виконують наступні завдання: регулювання положення візка чи утримання його у нерухомому стані (якщо спортивний асистент залишається у зоні гравця, але не тримає візок, це не вважається порушенням); передавання м'яча спортсменові; перекочування м'яча, щоб надати йому більш сферичної форми.

Пари для спортсменів класифікації ВС3. Гравці мають бути класифіковані як такі, що можуть грати в індивідуальній дисципліні ВС3. Пара ВС3 має включати також запасного гравця. Винятки можливі лише на розсуд BISFed, чиє рішення остаточне. Пара ВC3 має включати щонайменше одного гравця 3 церебральним паралічем на корті. Кожен спортсмен може користуватися допомогою спортивного асистента згідно з правилами, які регулюють індивідуальну гру. Правила гри у цій категорії такі ж, як і для команд, за винятком використання зон/боксів 2-5 у відповідному порядку. Спортивний асистент не повинен мати прямий фізичний контакт зі спортсменом під час здійснення кидка. Зокрема, не можна допомагати спортсменові, штовхаючи або змінюючи положення візка чи вказівника.

Пари для спортсменів класифікації BC4. Гравці мають бути класифіковані як такі, що можуть грати в індивідуальній дисципліні ВС4. Пара ВC4 має включати також запасного гравця. Винятки можливі лише на розсуд BISFed, чиє рішення остаточне. Правила гри у цій категорії такі ж, як і для команд, за винятком використання зон 2-5 у відповідному порядку.

Команди для спортсменів, класифікованих як BC1 та ВC2. Гравці мають бути класифіковані як такі, що можуть грати в індивідуальних категоріях ВC1 чи ВС2. Команда має включати щонайменше одного спортсмена ВC1 на корті. Кожній команді дозволено мати одного спортивного асистента, який має дотримуватися правил, що регулюють індивідуальну дисципліну ВС1. Кожна команда повинна розпочати матч із трьома спортсменами на корті та може мати до двох запасних гравців. У випадку, якщо запасних гравців двоє, у команді має бути два спортсмени $\mathrm{BC} 1$. Спортивний асистент не повинен мати прямий фізичний контакт зі спортсменом під час удару по м’ячі.

У ході досліджень апробувалися заняття з бочче (як метод фізичноспортивної реабілітації) з метою покращення сенсорної системи. Особи віком від 28 до 35 із тетрапарезом (ДЦП), які проходять курс реабілітації, у реабілітаційному центрі м. Львів.

На основі аналізу сенсорних систем у 10 молодих осіб, які мали клінічний діагноз: «Дитячий церебральний параліч» 3 руховими порушеннями середньої тяжкості, що пересувалися з допомогою візка виявлено, що у 9 із 10 учасників дослідження є дизартричні розлади.

Загальне соматичне ослаблення й сповільненість розвитку локомоторних функцій супроводжуються відставанням у розвитку рухової сфери в осіб із ДЦП. У зв'язку із цим проведені дослідження на виявлення порушень за шкалою SIPT (Sensory Integration and Praxis Tests), результати зведені у таблиці 1. 
Оцінки за SIPT

Таблиия 1.

\begin{tabular}{|l|c|c|c|c|c|c|c|c|c|c|}
\hline \multicolumn{1}{|c|}{ Тест } & \multicolumn{7}{|c|}{ Стандартизований бал } \\
\hline Кінестезія (КІN) & $-1,2$ & $-1,2$ & -1 & -1 & $-1,2$ & 0 & - & 0 & $-1,2$ & $-1,2$ \\
\hline $\begin{array}{l}\text { Постуральний праксис } \\
\text { (РPr) }\end{array}$ & $-1,2$ & -1 & $-1,2$ & -1 & 0 & $-1,2$ & 0 & $-1,2$ & 0 & -1 \\
\hline $\begin{array}{l}\text { Білатеріальна моторна } \\
\text { координація (ВМС) }\end{array}$ & -1 & $-1,2$ & $-1,2$ & -1 & $-1,2$ & 0 & - & $-1,2$ & 0 & $-1,2$ \\
\hline Моторна точність (МАС) & $-1,2$ & $-1,2$ & -1 & 0 & $-1,2$ & 0 & - & $-1,2$ & $-1,2$ & $-1,2$ \\
\hline
\end{tabular}

За результатами проведення оцінки виявлено, що у більшості осіб з ДЦП явна соматодиспраксія через низький бал, результати яких подано у таблиці 1. Про наявність сенсорно-інтегративної основи диспраксії можна говорити, коли спостерігаються труднощі 3 опрацювання інформації вестибулярної, пропріоцептивної та соматосенсорної систем.

Результати дослідження. Основний акцент під час проведення занять бочче полягав у застосуванні пропріоцептивних відчуттів.

Для осіб з ДЦП характерне недорозвинення тонко координованих рухів пальців рук, нерозуміння рухових установок, просторові й ритмічні порушення, ізольованість і нерозмірність рухів. Гравці зазнавали труднощів при відтворенні певного положення пальців рук під час кидку м'яча. У них спостерігалися дискоординовані рухи, неточності, сповільнене утворення рухових диференційовок (м'язового відчуття). Трудність у концентрації уваги над триманням м'яча та кидком у ціль.

Умови виконання вправ із кидком м'ячів набагато важчі, коли потрібно потрапити у ціль та втримувати баланс тіла, тому що вправи виконуються в постійному балансуванні, i, для того щоб не впасти, необхідно поєднувати центр ваги тіла. Ускладнені умови роботи дозволяють одержати швидкі результати за короткий час. Заняття 3 бочче мають оздоровче, виховне, корекційно-розвиваюче значення для всієї психомоторики та емоційновольової сфери осіб із ДЦП.

Як результат зменшення страху перед рухом покращилося моторне планування та регулювання положення тіла.

Через місяць після проведення занять зроблено повторну діагностику і виявлено покращення (див. Таблиця 2). 
Таблиия 2.

Повторна діагностика

\begin{tabular}{|c|c|c|c|c|c|c|c|c|}
\hline \multicolumn{3}{|c|}{$\begin{array}{l}\text { Порушення модулячії } \\
\text { сенсорних відчуттів }\end{array}$} & \multicolumn{3}{|c|}{ Контроль очима } & \multicolumn{3}{|c|}{ Адаптивні відповіді } \\
\hline 123 & $\begin{array}{c}\text { Загальне } \\
\text { збудження }\end{array}$ & 123 & 123 & $\begin{array}{c}\text { Роздільний } \\
\text { рух } \\
\text { око/голова }\end{array}$ & 123 & 123 & $\begin{array}{c}\text { Реакція на } \\
\text { пасивні } \\
\text { стимули }\end{array}$ & 123 \\
\hline 123 & $\begin{array}{l}\text { Тактильні } \\
\text { відчуття }\end{array}$ & 123 & 123 & $\begin{array}{c}\text { Швидка } \\
\text { локалізація }\end{array}$ & 123 & 123 & $\begin{array}{c}\text { Міцний } \\
\text { захват у } \\
\text { нерухомому } \\
\text { положенні } \\
\end{array}$ & 123 \\
\hline 123 & $\begin{array}{l}\text { Вестибулярні } \\
\text { відчуття }\end{array}$ & 123 & 123 & $\begin{array}{l}\text { Плавне } \\
\text { стеження }\end{array}$ & 123 & 123 & $\begin{array}{c}\text { Штовхає, } \\
\text { рухає, } \\
\text { розкачується }\end{array}$ & 123 \\
\hline
\end{tabular}

У таблиці 2 представлені конкретні цілі, які ставились до відновлення відповідних систем та середня оцінка показників до занять бочче (перша колонка) та після (друга колонка).

У ході проведення повторної діагностики встановлено, що відбулась зміна модуляції сенсорних відчуттів, а саме показників загального збудження і вестибулярних відчуттів. Також покращився контроль очима за усіма показниками - роздільний рух око/голова, швидка локалізація, плавне стеження. А також підвищились показники адаптивних відповідей.

Отже, під час проведення занять 3 бочче для осіб з порушенням опорно-рухового апарату було досягнуто основні цілі:

1 покращення схеми тіла для підтримування планування моторних дій;

2 покращення праксису (здатність планувати нові рухи), щоб особи могли більше застосовувати дрібну та грубу моторику.

Висновки: Проведене дослідження сенсорної системи людей з ДЦП після фізично-спортивної реабілітації показало, що участь у спорті та фізичному навантаженні сприяє підвищенню рівня фізичного здоров'я та покращення грубої дрібної моторики, пов'язаної із сенсорно-модуляторною системою. 